\title{
STRESS-STRAIN RELATIONSHIPS AND INFLUENCE OF TESTING PARAMETERS ON COUPON TEST RESULTS
}

Scientific paper / Znanstveni rad

Dokšanović, Tihomir

(Received: 3 May 2018; accepted: 12 June 2018)

University of Osijek, Faculty of Civil Engineering Osijek, Teaching/research assistant, PhD

Corresponding author: tdoksanovic@gfos.hr

Draganić, Hrvoje

University of Osijek, Faculty of Civil Engineering Osijek, Assistant professor

Radić, Ivan

University of Osijek, Faculty of Civil Engineering Osijek, Assistant professor

Damjanović, Domagoj

University of Zagreb, Faculty of Civil Engineering, Associate professor

\begin{abstract}
Tensile steel-coupon testing qualifies as one of the more commonly used experiments for determination of basic parameters for structural design. Such tests are usually performed to determine technical stress-strain relationships of tested materials. Technical stress-strain curves are not suitable for various numerical material models that exploit the plastic region of behavior, owing to the necking effect and accompanying change in coupon area being neglected during stress determination. Material ductility is influenced by the choice of gauge length, which may cause different researchers to differently interpret coupon tests of the same material. The proposed research utilizes benefits offered by an optical system for deformation monitoring to track changes in surface area and implement them during stress calculations until fracture. The possibility of adjusting the gauge length the same sample the ability to study its effect on obtained results. Based on analyzed data, these influences were evaluated and possible errors identified.
\end{abstract}

Keywords: coupon test; material properties; optical deformation monitoring; steel; true stress-strain

\section{RADNI DIJAGRAM I UTJECAJ PARAMETARA ISPITIVANJA NA REZULTATE VLAČNIH ISPITIVANJA}

Sažetak: Vlačno ispitivanje čeličnih epruveta je jedan od češćih eksperimenata, za praktične i znanstvene svrhe, prvenstveno jer daje osnovu za određivanje baznih varijabli koje su potrebne prilikom dimenzioniranja. Uobičajeni rezultat vlačnog ispitivanja je tehnički radni dijagram naprezanje - relativna deformacija. Međutim, on nije pogodan za različite numeričke modele materijala pomoću kojih se iskorištava plastično područje ponašanja, vezano uz činjenicu da se učinak suženja i pripadne promjene površine poprečnog presjeka epruvete zanemaruju pri određivanju naprezanja. Duktilnost je pod utjecajem odabrane mjerne duljine, što kao posljedicu može imati da različiti istraživači tumače rezultate vlačnog ispitivanja istog materijala na različite načine. Provedeno istraživanje iskorištava prednosti optičkog sustava za prostorno snimanje deformacija, tako da se prate promjene ploštine poprečnog presjeka i uzimaju u obzir pri proračunu naprezanja, sve do loma. Mogućnost promjene mjerne duljine na uzorku omogućila je proučavanje tog učinka na rezultate. Na temelju analize dobivenih podataka, navedeni utjecaji su procijenjeni i utvrđene su moguće pogreške.

Ključne riječi: epruveta; mehanička svojstva; optičko mjerenje deformacija; čelik; stvarni radni dijagram 


\section{INTRODUCTION}

Steel is a popular material used in structural engineering, and determination of its mechanical properties is important with regard to structural design and research. Consequently, tensile coupon tests are one of the most common laboratory procedures, which highlights the importance of prescribing testing parameters and shapes of samples as a basis for quality and comparability of obtained results.

Testing procedures previously developed, along with universal testers and available materials, made the currently valid EN ISO 6892-1 [1] an internationally accepted standard. However, there exist certain guidelines that lead to deviations in obtained results, thereby serving as a source of variability in mechanical properties. For instance, selection of different gauge lengths and testing rates lead to different strain values being recorded at a certain corresponding stress level and vice versa. Additionally, coupon cross-section reduction during testing is often difficult, and at times, nearly impossible to monitor. This, in turn results in determination of an engineering stress-strain curve, which although commonly used, is not representative of the true plasticity of materials.

The influence of test rate (speed) on metallic materials has previously been investigated in studies reported by Krempl and Khan [2] as well as Huang and Young [3] that provide test results and recommendations for various metals. These studies conclude that yield- and ultimate-strength values are sensitive to the loading rate even within valid lower- and upper-bound values in accordance with European, Australian, and American standards [4-6].

The influence of gauge-length choice on test results is difficult to evaluate using classical instruments based on making contact with the sample. Furthermore, strain control is sometimes difficult to establish with metals that display yield, since strain distribution along a direction parallel to specimen length is not uniform, i.e., strain remains localized within Lüders bands outside of the extensometer gauge length. In addition, insight into the true stressstrain behavior is hardly possible to gain using classical instrumentation. Digital image correlation represents a possible measurement technique that promotes active measurement of the entire coupon surface, thereby facilitating more in-depth analyses to be performed [7]. The essence of this technique lies in the analysis of photographs, captured over the entire displacement field, in indefinite ways and on the same sample.

It is clear that there exist important aspects of tensile coupon-testing parameters that require further investigation.

Consequently, the purpose of this research is to investigate the influence of gauge lengths on obtained mechanical properties of materials, within valid upper and lower bounds of EN ISO 6892-1 [1]. The said objective was accomplished through use of an optical deformation measuring system based on spatial digital image correlation. Additionally, use of such a system allows for evaluation and correlation of differences between engineering and true stress-strain curves of steel samples. This has also been accomplished in the proposed study.

\section{NORMATIVE APPROACH}

Insight into the behavior of metals can be gained via tensile testing, which involves analysis of the graphical representation of stress versus relative strain curve (Figure 1). The EN ISO 6892-1 standard [1], which superseded the popular EN 10002-1 standard [8], provides guidelines on how to perform tensile tests on metals at room temperature. 


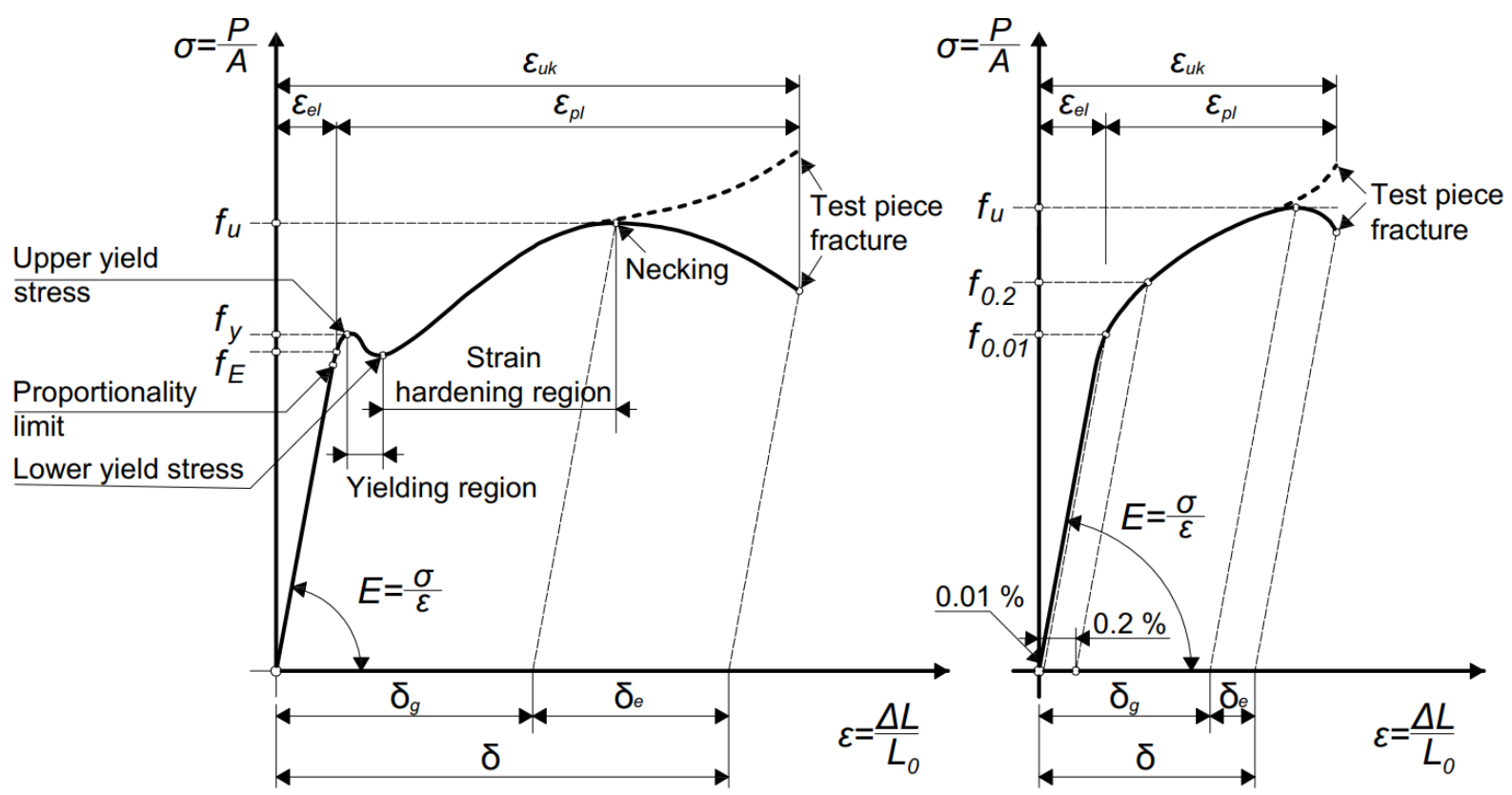

Figure 1 Stress-strain curves of a metal with (left) and without (right) a pronounced yield stress

\subsection{Test coupons and gauge length}

The procedure of testing acknowledges the influence of product shape and thickness on results of a tensile test, and thus, annexes in EN ISO 6892-1 [1] provide recommendations based on parameters listed in Table 1. Coupons preferred in EN ISO 6892-1 [1] have a functional relationship between the gauge length $\left(L_{0}\right)$ and cross-sectional area $\left(A_{0}\right)$ expressed as $L_{0}=k \cdot \sqrt{A_{0}}$, wherein $k$ denotes the coefficient of proportionality, which has been internationally accepted as 5.65 . Gauge length should not measure less than $15 \mathrm{~mm}$, and in case the crosssectional area is too small to fulfil this requirement, a value of $k=11.3$ has been suggested to be used.

Table 1 Possible types of coupons in accordance with the EN ISO 6892-1 standard [1]

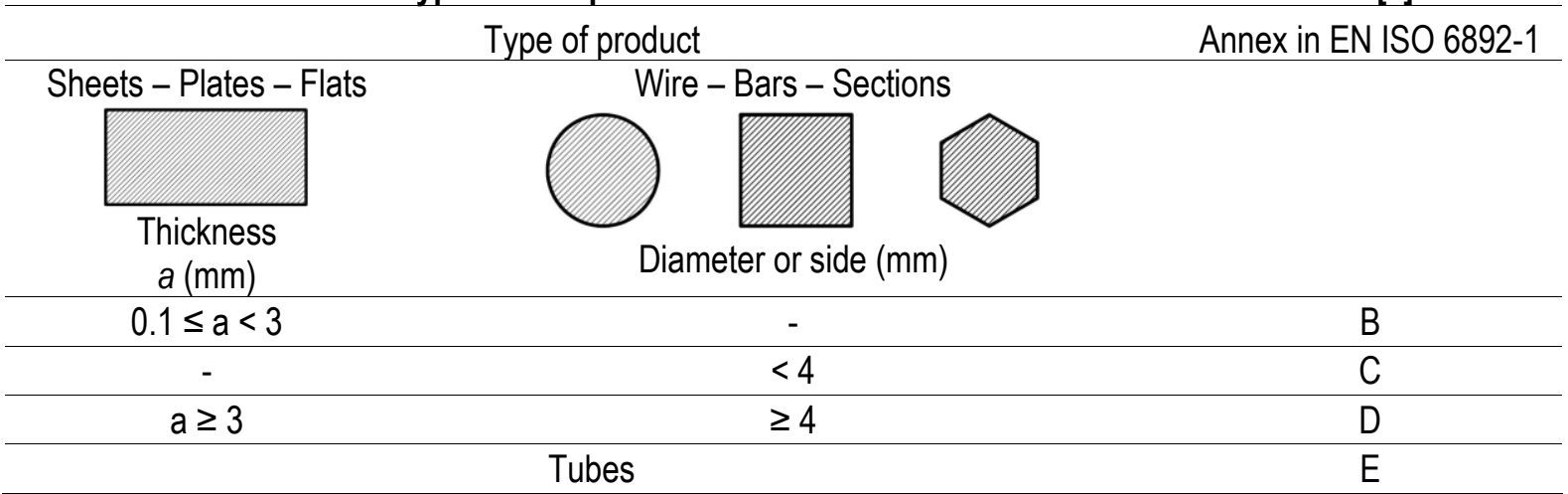

Note: 1 inch $=25.4 \mathrm{~mm}$.

Machined coupons must incorporate a transition radius between gripped ends ( 1 in Figure 2 ) and the parallel length ( $L_{c}$ in Figure 2), with dimensions being determined in accordance with the appropriate annex (Table 1). In case there exists no transition radii, it is necessary to ensure existence of a sufficient length between the grips and gauge marks $\left(L_{0}\right.$ in Figure 2). When coupon strains are being determined through use of an extensometer, the gauge length $L_{0}$, in fact, represents the extensometer gauge length $L_{\mathrm{e}}$. For proportional coupons, the calculated gauge length $L_{0}$ can be rounded to the nearest multiple of $5 \mathrm{~mm}$, as long as the difference between calculated and marked gauge lengths measures less than $10 \%$. The extensometer length $L_{e}$ must measure greater than $0.5 L_{0}$ but less than $0.9 L_{c}$ for accurate measurement of yield- and proof-strength parameters, whereas for parameters at and after determination of the tensile strength $L_{e}$ must approximately be equal to $L_{0}$.

Dokšanović, T, Draganić, H, Radić, I, Damjanović, D 


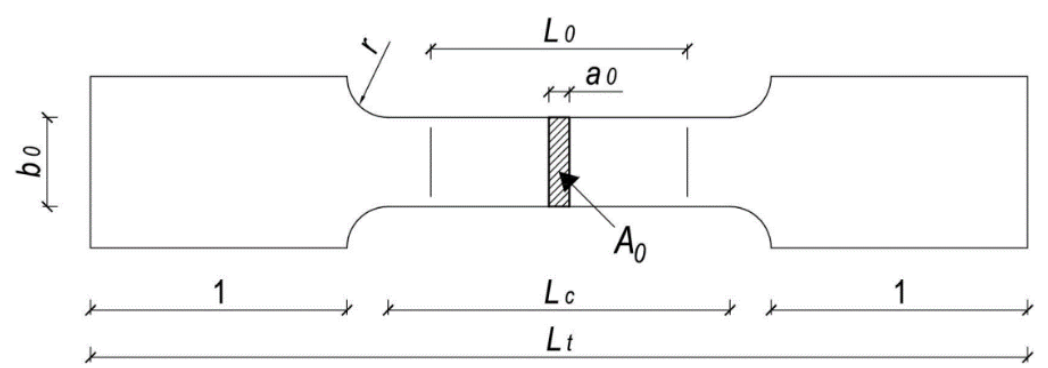

Figure 2 Machined proportional test coupon for tensile tests

\subsection{Testing rate}

The testing rate depends on the modulus of elasticity value as well as properties sought after (area of the stressstrain curve), and can be controlled via strain (method A) or stress (method B) rates (Figure 3). Strain rate can be established based on feedback obtained from an extensometer or crosshead separation rate, whereas stress rate can be established based on load-cell readings, within limits of stress and strain rates.

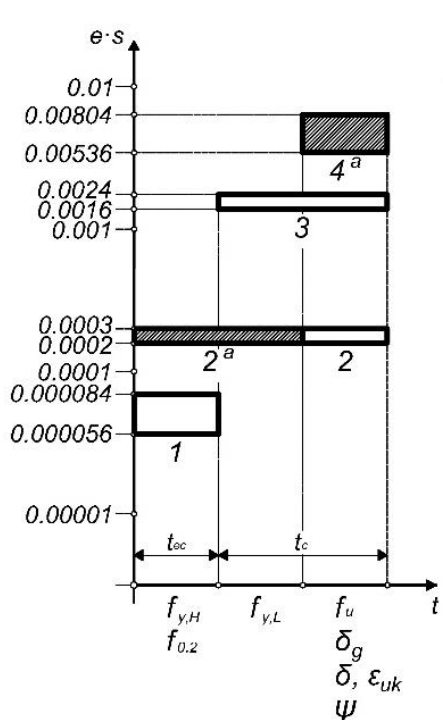

Method A

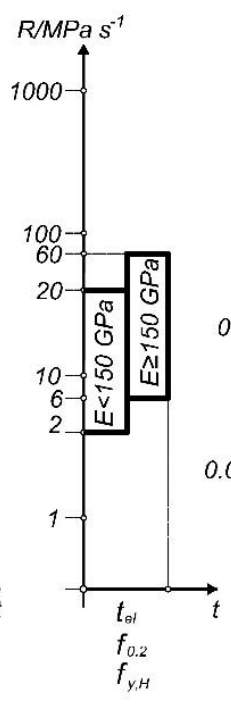

$$
\downarrow
$$

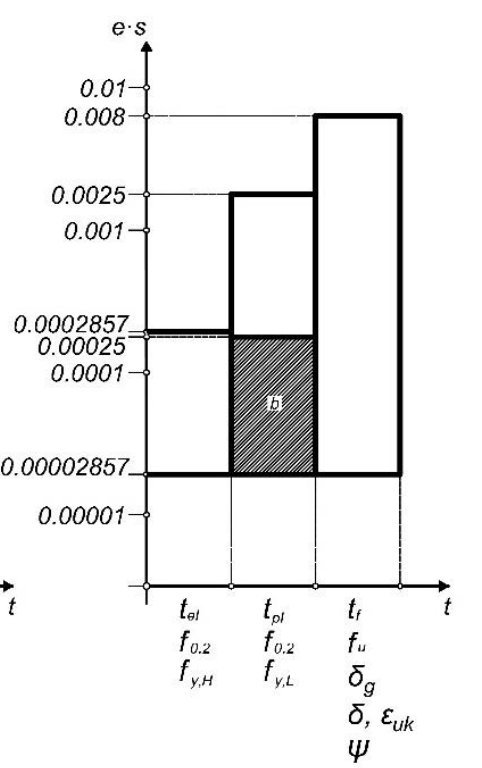

Method B

Figure 3 Method A (strain rate) and B (stress rate) in accordance with EN ISO 6892-1 [1]

\section{EXPERIMENTAL INVESTIGATION}

\subsection{Test specimens}

To determine the influence of gauge-length choice on tensile coupon-test results as well as evaluate and correlate differences between engineering and true stress-strain curves, experiments were performed using three test specimens cut from plates made of steel grade S 235, in accordance with EN 10025-2 [9], and machined to form a proportional test coupon with a rectangular cross section. Samples were cut from steel plates measuring $6-\mathrm{mm}$ thick, and thus, nominal dimensions of coupons were chosen in accordance with rules for rectangular samples prescribed in annex D of EN ISO 6892-1 [1] ( Figure 4). 


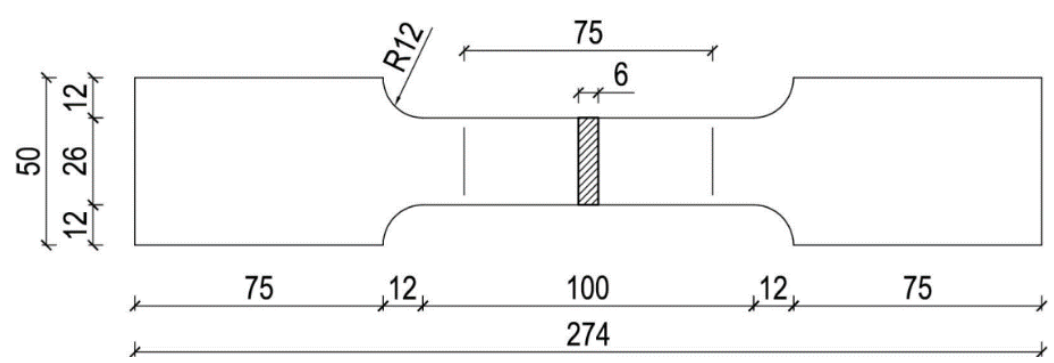

Figure 4 Nominal test-coupon dimensions in $\mathrm{mm}$

Machining tolerances must be fulfilled, if the nominal surface area $A_{0}$ is used in calculations without measuring actual test pieces. In this study, therefore, test pieces were measured, after machining, through use of a Vernier caliper with a precision of $0.1 \mathrm{~mm}$, and corresponding measured values are listed in Table 2.

Table 2 Nominal and measured test coupons dimensions

\begin{tabular}{|c|c|c|c|c|c|c|}
\hline \multicolumn{2}{|c|}{ Dimension } & $L_{0}(\mathrm{~mm})$ & $L_{c}(\mathrm{~mm})$ & $L_{t}(\mathrm{~mm})$ & $b_{0}(\mathrm{~mm})$ & $a_{0}(\mathrm{~mm})$ \\
\hline \multicolumn{2}{|c|}{$\begin{array}{l}\text { Annotation from } \\
\text { EN ISO 6892-1 }\end{array}$} & $L_{0}=5.65 \cdot \sqrt{A_{0}}$ & $L_{c} \geq L_{0}+1.5 \cdot \sqrt{A_{0}}$ & 7 & \multicolumn{2}{|c|}{$b_{0} / a_{0}>8.0$} \\
\hline \multirow[t]{2}{*}{ Nomin } & & 75.0 & 100.0 & 274.0 & 26.0 & 6.0 \\
\hline & E1 & 75.0 & 100.0 & 273.5 & 26.0 & 6.0 \\
\hline \multirow[t]{2}{*}{ Measured } & E2 & 75.0 & 100.0 & 273.4 & 26.1 & 6.0 \\
\hline & E3 & 75.0 & 100.0 & 274.0 & 26.0 & 6.0 \\
\hline
\end{tabular}

Note: 1 inch $=25.4 \mathrm{~mm}$.

\subsection{Test setup and procedure}

Tensile tests were performed using the Shimadzu AG-X Autograph universal tester [10] with a maximum loading capacity of $300 \mathrm{kN}$ and the ability control strain and stress rates using the Shimadzu Trapezium X software [11]. Test-piece deformation (strain) under loading was monitored using an optical digital image correlation systemGOM Aramis [12, 13]. Position of the Shimadzu AG-X crosshead (upper grip) was constantly monitored to measure the relative displacement between grips. Both listed machines comply with accuracy requirements during testing, as prescribed in EN ISO 6892-1 [1].

The loading procedure was performed in accordance with EN ISO 6892-1:2016 B3.2 [4] at a data-sampling frequency of $10 \mathrm{~ms}(100 \mathrm{~Hz})$. Utilized stress $(3.2 \mathrm{MPa} / \mathrm{s})$ and strain rates in the elastic and plastic regions were lower than recommended, thereby facilitating attainment of higher sampling quality from GOM Aramis-i.e., more data points and finer detection of important changes.

The GOM Aramis 5M system was set-up for determination of 3D deformations and calibrated using a certified object to monitor measuring volumes of $150 \times 130 \mathrm{~mm}$, within which a strain accuracy of up to $0.01 \%$ was established. Since test specimens lack contrast, they were prepared for monitoring via application of a stochastic pattern using black and white color sprays. Data sampling (recording rate) for the GOM Aramis system was chosen based on a preliminary tensile test duration. Figure 5 depicts all components of the test setup together with the test specimen on which the stochastic pattern was applied. 

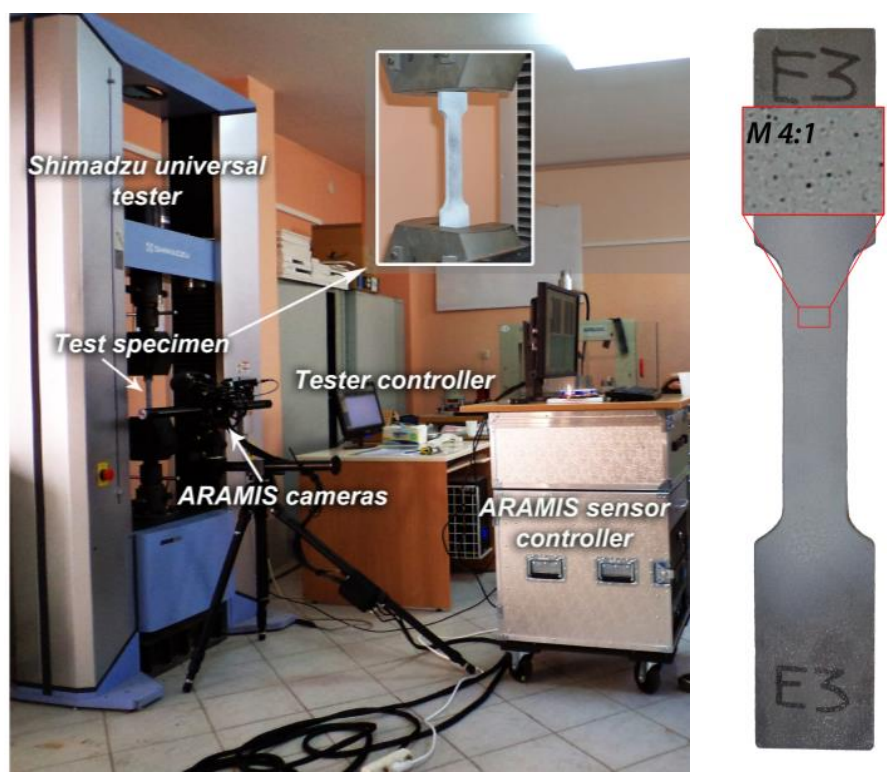

Figure 5 Test setup along with applied stochastic color-spray pattern on test specimen E3

\section{RESULTS AND DISCUSSION}

Obtained raw data was processed using the GOM Aramis software package [12], wherein preparation of photos was also accomplished. The preparation procedure included coordinate-axis alignment, so that a plane matched the specimen surface with an axis parallel to the specimens length $L_{c}$.

\subsection{Influence of gauge length}

The EN ISO 6892-1 [1] standard enables application of different extensometer gauge lengths, and influence of these gauge lengths on test results was determined. For investigated test specimens, in accordance with section 2.1, allowable gauge lengths lied in the range of $37.5 \mathrm{~mm}$ and $90 \mathrm{~mm}$.

The GOM Aramis software facilitates use of a point-point distance element tool to track the distance between two selected points across all captured images with respect to an "initial" image (the first image captured during test), which in fact, acts as a virtual extensometer. For each test specimen, six such elements were applied with 10-mm increments $-40 \mathrm{~mm}, 50 \mathrm{~mm}, 60 \mathrm{~mm}, 70 \mathrm{~mm}, 80 \mathrm{~mm}$, and $90 \mathrm{~mm}$ (Figure 6). The visible surface of specimens was divided into a regular facet mesh with coordinates at each corner of a facet, thereby stipulating that the initial point-to-point element distance does not equal the nominal length (Table 3).

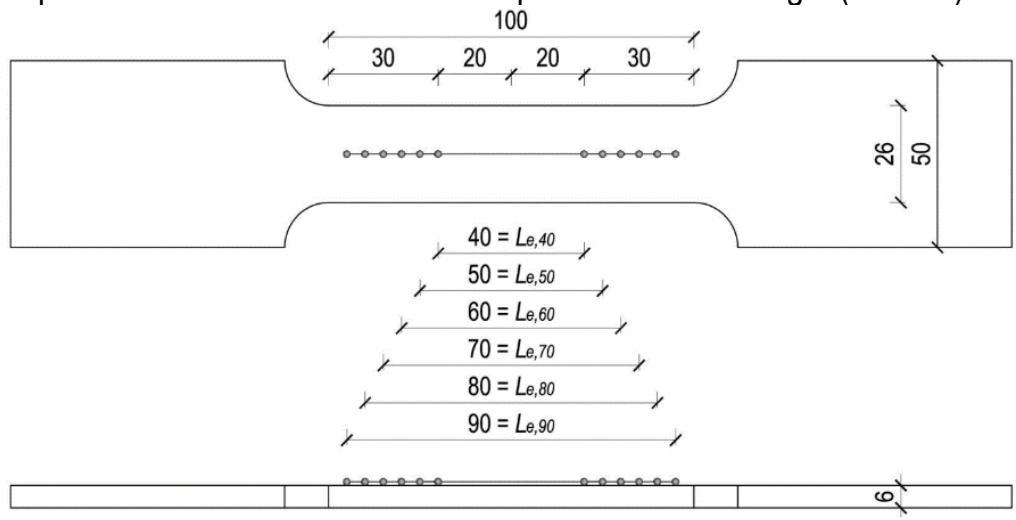

Figure 6 Nominal and investigated virtual extensometer gauge lengths (in $\mathrm{mm}$ ) 
Table 3. Actual gauge lengths of virtual extensometers.

\begin{tabular}{ccccccc}
\hline Test specimen & $L_{e, 40}(\mathrm{~mm})$ & $L_{e, 50}(\mathrm{~mm})$ & $L_{e, 60}(\mathrm{~mm})$ & $L_{e, 70}(\mathrm{~mm})$ & $L_{e, 80}(\mathrm{~mm})$ & $L_{e, 90}(\mathrm{~mm})$ \\
\hline E1 & 40.48 & 49.86 & 60.29 & 70.73 & 80.14 & 90.62 \\
E2 & 39.81 & 50.32 & 59.81 & 70.35 & 79.83 & 90.42 \\
E3 & 39.92 & 50.46 & 59.97 & 70.54 & 80.11 & 89.62 \\
\hline
\end{tabular}

Note: 1 inch $=25.4 \mathrm{~mm}$.

For each test specimen, full-field deformations under conditions of yield stress, ultimate tensile strength, and fracture were determined in order to verify a regular strain state and whether the virtual extensometer was placed at a relevant position with no issues concerning misalignment or gripping (e.g., test sample depicted in Figure 7). Determined mechanical material properties of test coupons, sorted using virtual extensometer gauge lengths, are summarized in Table 4, and corresponding stress-strain curves are depicted in Figure 8. Modulus of elasticity values listed in Table 4 are based on a linear regression of stress over strain between lower and upper stress values corresponding to $10 \%$ and $40 \%$ of the yield stress, respectively, in accordance with recommendations of EN ISO 6892-1 [1]. The number of data points exceeded 50 in all analyzed cases.
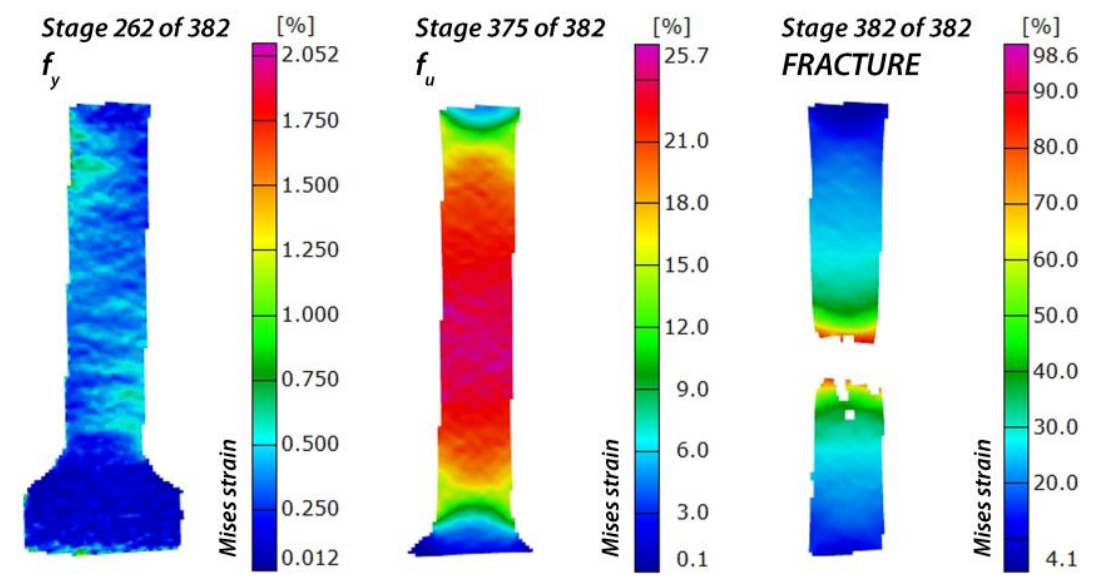

Figure 7 Full-strain field for test specimen E3 at relevant stresses (GOM Aramis)

Table 4 Determined properties of test coupons sorted using virtual extensometer gauge length

\begin{tabular}{|c|c|c|c|c|c|c|c|c|c|}
\hline \multicolumn{2}{|c|}{ Gauge length } & $L_{e, 40}$ & $L_{e, 50}$ & $L_{e, 60}$ & $L_{e, 70}$ & $L_{e, 80}$ & $L_{e, 90}$ & Mean & CoV \\
\hline \multirow{3}{*}{$E(\mathrm{MPa})$} & E1 & 185743 & 196560 & 204269 & 196469 & 191162 & 196466 & 195112 & 0.032 \\
\hline & E2 & 197559 & 186495 & 200365 & 193585 & 199087 & 194039 & 195188 & 0.026 \\
\hline & E3 & 193944 & 202942 & 216251 & 204771 & 195849 & 212743 & 204417 & 0.043 \\
\hline \multirow{3}{*}{$\boldsymbol{f}_{\boldsymbol{y}}(\mathrm{MPa})$} & E1 & \multicolumn{6}{|c|}{262} & - & - \\
\hline & E2 & \multicolumn{6}{|c|}{264} & - & - \\
\hline & E3 & \multicolumn{6}{|c|}{266} & - & - \\
\hline \multirow{3}{*}{$\boldsymbol{f}_{u}(\mathrm{MPa})$} & E1 & \multicolumn{6}{|c|}{378} & - & - \\
\hline & E2 & \multicolumn{6}{|c|}{381} & - & - \\
\hline & E3 & \multicolumn{6}{|c|}{383} & - & - \\
\hline \multirow{3}{*}{$\varepsilon_{y}(\%)$} & E1 & 0.369 & 0.397 & 0.409 & 0.419 & 0.410 & 0.401 & 0.401 & 0.043 \\
\hline & E2 & 0.328 & 0.328 & 0.323 & 0.324 & 0.338 & 0.338 & 0.330 & 0.020 \\
\hline & E3 & 0.346 & 0.349 & 0.353 & 0.358 & 0.364 & 0.367 & 0.356 & 0.024 \\
\hline \multirow{3}{*}{$\varepsilon_{u}(\%)$} & E1 & 21.6 & 21.8 & 22.0 & 22.0 & 21.6 & - & 21.8 & 0.010 \\
\hline & E2 & 24.6 & 24.5 & 24.4 & 24.2 & 24.0 & 23.3 & 24.1 & 0.020 \\
\hline & E3 & 23.4 & 23.2 & 22.9 & 22.5 & 22.1 & 21.5 & 22.6 & 0.031 \\
\hline \multirow{3}{*}{$\boldsymbol{\varepsilon}_{\max }(\%)$} & E1 & 38.4 & 39.1 & 38.4 & - & - & - & 38.6 & 0.010 \\
\hline & E2 & 39.1 & 43.8 & 41.6 & 39.5 & 37.7 & 32.4 & 39.0 & 0.099 \\
\hline & E3 & 43.6 & 40.1 & 37.6 & 35.4 & 33.6 & 31.9 & 37.0 & 0.116 \\
\hline
\end{tabular}

Note: 1 inch $=25.4 \mathrm{~mm} ; 1 \mathrm{ksi}=6.89 \mathrm{MPa} ; \mathrm{CoV}=$ coefficient of variation. 

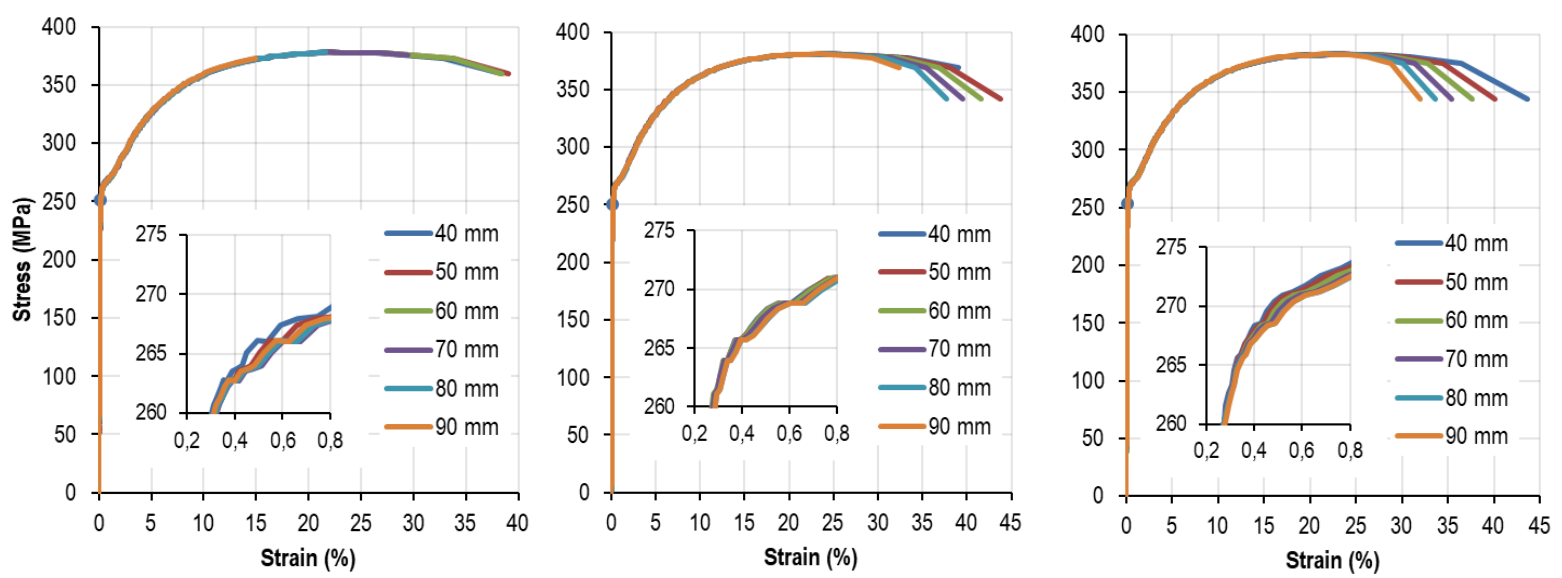

Figure 8 Stress-strain curves for test specimens E1 (left), E2 (middle), and E3 (right)

Results for test specimen E1 (Figure 8; Table 4) were observed to be of lower quality, since an increase in gauge length led to earlier termination of strain reading owing to coinciding of the test-specimen fracture area with the virtual extensometer grip. Such a possibility exists when employing a classical extensometer, and the said results were, therefore, accepted as valid but less representative (invalid values were filtered from Table 4). The greatest difference in modulus of elasticity values, as a function of gauge length, for specimen $\mathrm{E} 1$ was determined between gauge lengths measuring $40 \mathrm{~mm}(185743 \mathrm{MPa}$ ) and $60 \mathrm{~mm}$ (204 $269 \mathrm{MPa}$ ), being 9.97\% (Table 5).

Strain values corresponding to the yield stress were observed to differ by $13.57 \%$ over a gauge-length range of $40-70 \mathrm{~mm}$, wherein the said strain values demonstrate the greatest variation (coefficient of variation). Table 5 presents a trend of increase in gauge length causing a corresponding decrease in differences between measured values of modulus of elasticity and strain at yields stress.

As regards specimen E2 (Figure 8; Table 4), greatest deviations with respect to gauge length were observed in the values of modulus of elasticity and maximum strain, the corresponding coefficients of variation being 0.026 and 0.099 , respectively. In accordance with the determined variability, the greatest difference between observed minimum and maximum values was determined for these properties between $L_{e, 50}$ and $L_{e, 60}$ (Table 5). Using a gauge length of $50 \mathrm{~mm}$ resulted in development of the greatest strain at fracture $(43.8 \%)$, whereas a gauge length of $90 \mathrm{~mm}$ yielded the lowest strain at fracture (32.4\%). Correspondingly, an increase in gauge length led to reduced strain at ultimate stress.

Table 5 Differences in key properties depending on utilized gauge length

\begin{tabular}{|c|c|c|c|c|c|c|c|c|c|c|}
\hline Property & ja & $\leftrightarrow$ & I & $\leftrightarrow$ & $\stackrel{8}{5}$ & 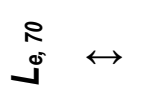 & $\underset{\sim}{\infty} \leftrightarrow \stackrel{8}{\tilde{j}}$ & $\underset{\mathbf{z}}{\mathfrak{z}}$ & $\leftrightarrow$ & $\stackrel{x}{\Sigma}$ \\
\hline \multirow{3}{*}{$E$} & E1 & $5.82 \%$ & & $3.92 \%$ & $3.97 \%$ & $2.78 \%$ & $2.77 \%$ & $185743 \mathrm{MPa}$ & $9.97 \%$ & $204269 \mathrm{MPa}$ \\
\hline & E2 & $5.93 \%$ & & $7.44 \%$ & $3.50 \%$ & $2.84 \%$ & $2.60 \%$ & $186495 \mathrm{MPa}$ & $7.44 \%$ & $200365 \mathrm{MPa}$ \\
\hline & E3 & $4.64 \%$ & & $6.56 \%$ & $5.61 \%$ & $4.56 \%$ & $8.63 \%$ & $193944 \mathrm{MPa}$ & $11.50 \%$ & $216251 \mathrm{MPa}$ \\
\hline \multirow{3}{*}{$\varepsilon_{y}$} & $E 1$ & $7.55 \%$ & & $3.01 \%$ & $2.51 \%$ & $2.10 \%$ & $2.24 \%$ & $0.369 \%$ & $13.57 \%$ & $0.419 \%$ \\
\hline & E2 & $0.02 \%$ & & $1.44 \%$ & $0.29 \%$ & $4.25 \%$ & $0.07 \%$ & $0.323 \%$ & $4.62 \%$ & $0.338 \%$ \\
\hline & E3 & $0.77 \%$ & & $1.37 \%$ & $1.32 \%$ & $1.71 \%$ & $0.75 \%$ & $0.346 \%$ & $6.07 \%$ & $0.367 \%$ \\
\hline \multirow{3}{*}{$\varepsilon_{u}$} & $E 1$ & $1.27 \%$ & & $0.84 \%$ & $0.15 \%$ & $1.73 \%$ & - & $21,57 \%$ & $2,13 \%$ & $22.03 \%$ \\
\hline & E2 & $0.51 \%$ & & $0.27 \%$ & $0.74 \%$ & $1.09 \%$ & $2.88 \%$ & $23.28 \%$ & $5.58 \%$ & $24.58 \%$ \\
\hline & E3 & $1.17 \%$ & & $1.36 \%$ & $1.39 \%$ & $1.89 \%$ & $2.86 \%$ & $21.51 \%$ & $8.97 \%$ & $23.44 \%$ \\
\hline \multirow{3}{*}{$\boldsymbol{\varepsilon}_{\max }$} & $E 1$ & $1.64 \%$ & & $1.85 \%$ & - & - & 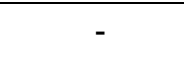 & $38,35 \%$ & $1,85 \%$ & $39.06 \%$ \\
\hline & E2 & $11.93 \%$ & & $5.10 \%$ & $5.40 \%$ & $4.74 \%$ & $16.32 \%$ & $32.43 \%$ & $34.96 \%$ & $43.76 \%$ \\
\hline & E3 & $8.74 \%$ & & $6.63 \%$ & $6.15 \%$ & $5.24 \%$ & $5.45 \%$ & $31.9 \%$ & $36.58 \%$ & $43.57 \%$ \\
\hline
\end{tabular}

Note: $1 \mathrm{ksi}=6.89 \mathrm{MPa} ; \mathrm{MIN}=$ lowest recorded value; $\mathrm{MAX}=$ highest recorded value. 
With regard to specimen E3 (Figure 8; Tables 4 and 5), results indicate that largest variations in values with respect to gauge lengths were observed in terms of strain values at fracture, the greatest difference being over the gauge-length range of $40-90 \mathrm{~mm}$. Maximum deviations in values of the modulus of elasticity (between gauge lengths of 40-60 mm), strain at yield stress (between gauge lengths of 40-90 mm) and strain at fracture (between gauge lengths of $40-90 \mathrm{~mm}$ ) were observed to be $11.5 \%, 6.07 \%$, and $8.97 \%$, respectively. An increase in gauge length led to increased strain values at yield stress and reduced strains at ultimate stress with no significant change in modulus of elasticity values.

Grouping together all test results and analyzing them as one demonstrated that the greatest average difference between modulus of elasticity values, with respect to changes in gauge length, equaled $9.64 \%$, and that the greatest average difference in strain at yield stress equaled $8.09 \%$. Strain at ultimate-stress demonstrated an average difference of $5.56 \%$, and the corresponding difference at fracture equaled $35.77 \%$ (without test specimen $\mathrm{E} 1$ values). Above percentage differences demonstrate significant variation, even in the region of loading prior to occurrence of ultimate tensile stress.

If results for all gauge lengths of individual specimens are reduced to their averages and represented in the form of a stress-strain curve (Figure 9), an evident compatibility can be observed. This implies that there exists a clear basis for their comparison and corresponding conclusions to be drawn based on trends dependent on the gauge length. Additionally, it can be seen that a larger variation in results exists in the loading region post realization of the ultimate tensile strength.

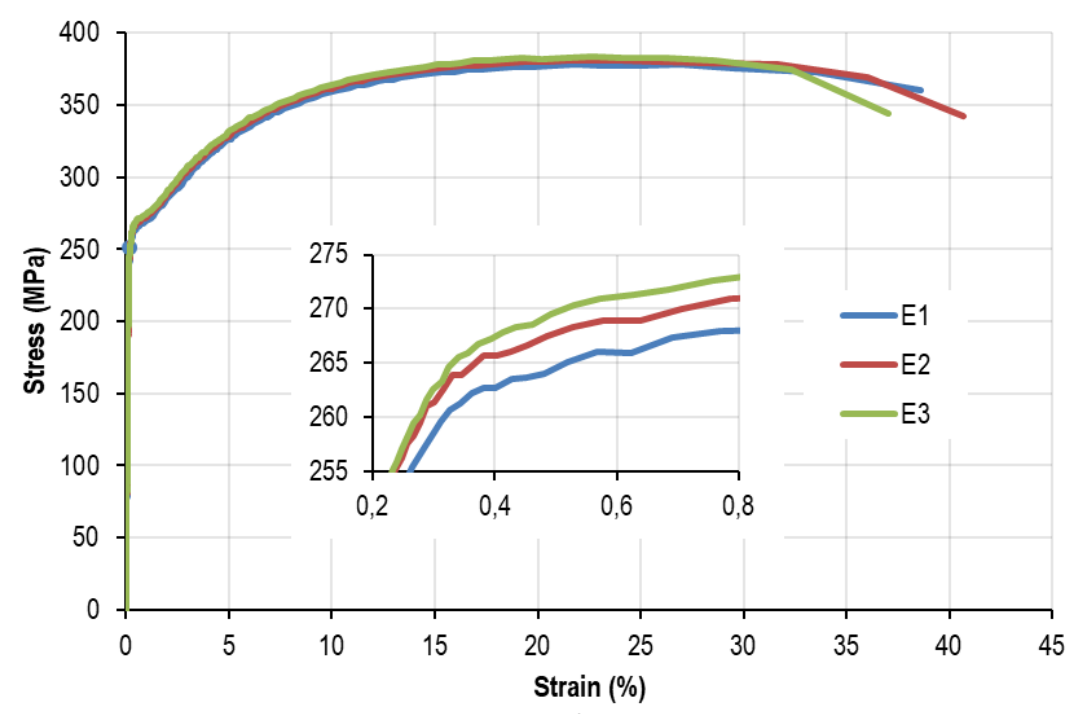

Figure 9 Average stress-strain curves of tests specimens E1, E2, and E3

\subsection{Influence of necking}

Test-specimen cross-sectional thickness and width reduction have a significant influence on tensile-test results; this influence, however, is almost always neglected. Application of GOM Aramis for monitoring deformations that occur during tensile testing facilitates determination of cross-sectional area changes at which specimens tend to fracture. This, in turn, facilitates determination of the true stress-strain curve.

Monitoring of changes in cross-sectional width is possible using an analysis element point-point distancea technique also used during gauge-length evaluation. The said tracking of cross-sectional thickness change was performed on the photographed side of test specimens using analysis element's point position. Since only one side of a sample is visible, symmetrical deformations were assumed $\left(a_{n}=a_{0}-2 z\right)$, the assumption being valid for rectangular cross sections made of an isotropic material (Figure 10). 


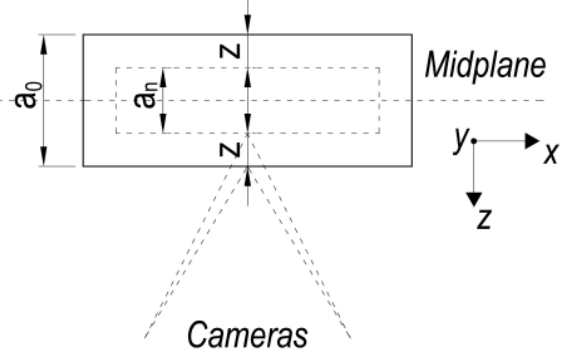

Figure 10 Basis for determination of dimension change in the direction of axis z-z

Analysis elements were placed at cross sections coincident with test-specimen fracture based on insights gained from photographs (stages) captured prior to fracture occurrence. Figure 11 depicts the layout of analysis elements used in this study-a) depicting point-point distance and b) point position.

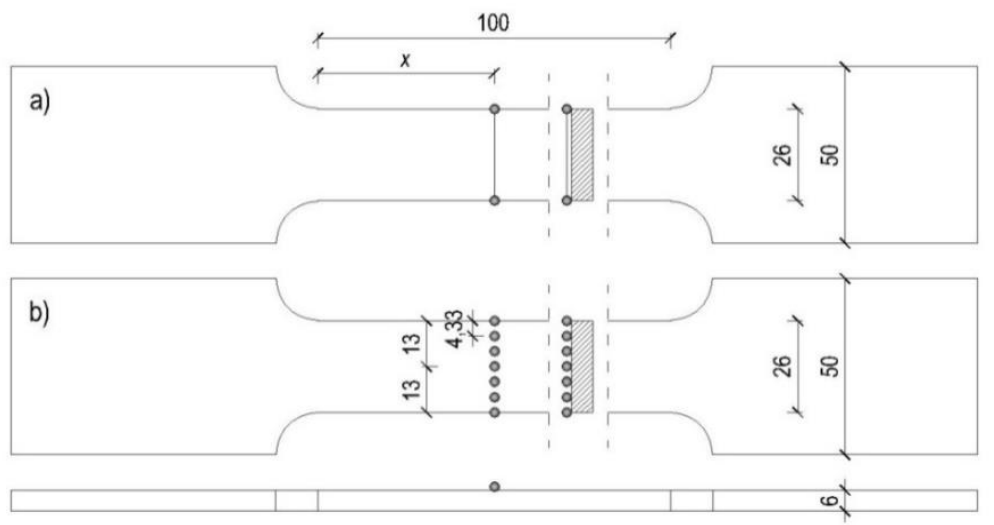

Figure 11 Layout: a) virtual extensometer for width-change tracking; b) virtual LVDT for thicknesschange monitoring (in $\mathrm{mm}$ )

Stress-strain trends corresponding to position $x$ in Figure 11(a) are depicted in Figure 12 demonstrating longitudinal deformations of test specimens at or near fracture. Figure 12 also clearly depicts basic principles of thickness- and width-change monitoring based on deformations observed in terms of spatial coordinates.

As observed, reduction in cross-sectional width and thickness of specimens influences the shape of their corresponding stress-strain curve beyond the yield stress, thereby also influencing the ultimate stress (Figure 13).

Observed stress-strain curves assume their theoretical shape with largest differences occurring at maximum strain values, thereby leading to significantly higher values of ultimate stress.

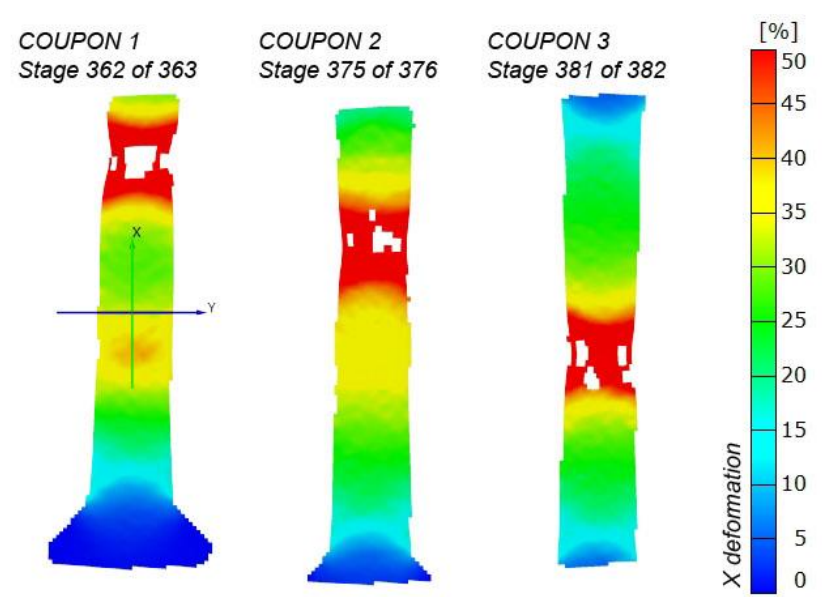

Figure 12 Elongation and corresponding change in cross-sectional width and thickness during fracture (GOM ARAMIS)

Dokšanović, T, Draganić, H, Radić, I, Damjanović, D 


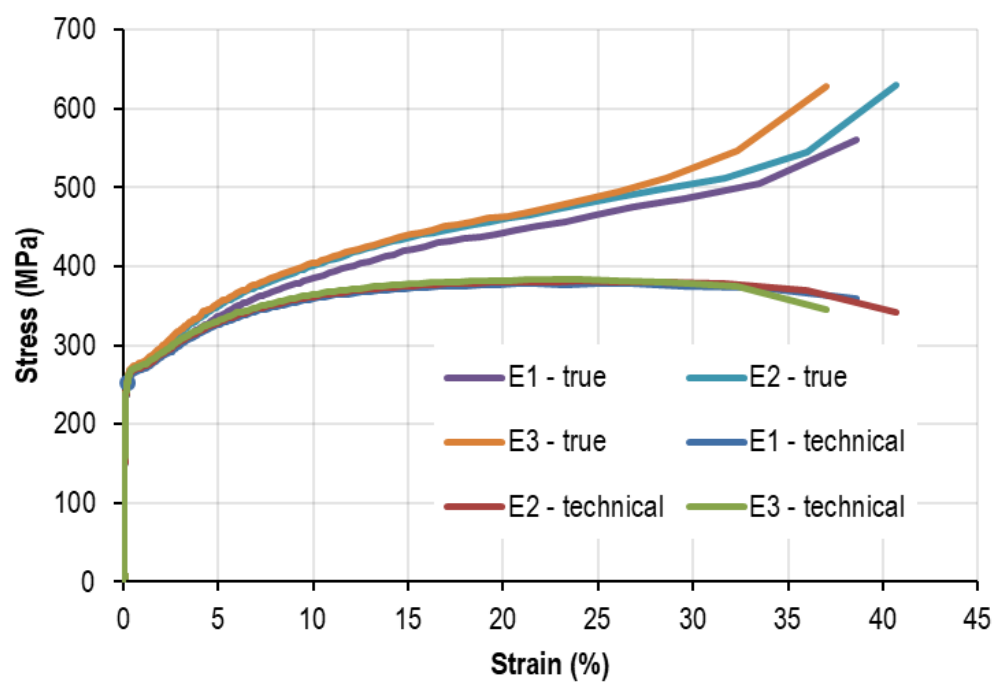

Figure 13 True average stress-strain curves for test specimens E1, E2, and E3 compared against corresponding technical stress-strain curves

Reduction in cross-sectional area with increase in strain for test specimen E2 results in a $19.36 \%$ increase in stress at a value of strain corresponding to the technical ultimate tensile stress; accordingly, the maximum value of tensile stress is observed to be $48.16 \%$ greater compared to its technical maximum value (Table 6). Taking only the width-reduction effect into account, the corresponding difference between maximum stress values equals $25.26 \%$.

Table 6 True stresses at relevant strains for test specimens E1, E2, and E3

\begin{tabular}{cccc}
\hline & & $\begin{array}{c}\text { Taking into account reduction in cross- } \\
\text { sectional width }\end{array}$ & $\begin{array}{c}\text { Taking into account reduction in cross- } \\
\text { sectional width and thickness }\end{array}$ \\
\hline Stress at & E1 & 415.69 & 451.34 \\
technical $f_{\mathrm{u}}$ strain & E2 & 419.96 & 479.77 \\
$(\mathrm{MPa})$ & $\mathrm{E} 3$ & 420.42 & 476.02 \\
Stress at & $\mathrm{E} 1$ & 447.25 & 560.25 \\
maximum strain & E2 & 442.35 & 629.54 \\
$(\mathrm{MPa})$ & $\mathrm{E} 3$ & 442.78 & 627.63 \\
\hline
\end{tabular}

Note: 1 ksi = 6.89 MPa; Technical ultimate stresses: E1 = 378.13 MPa; E2 = 380.88 MPa; $383.28 \mathrm{MPa}$.

When considering reduction in cross-sectional area along with increase in tensile force applied to test specimen E2 leads to a $65.29 \%$ increase in the maximum tensile stress (Table 6). Considering stresses corresponding to the technical value of the ultimate tensile strain, the corresponding percentage increase equals $25.96 \%$. Such large differences in stress values are justified by the fact that the cross-sectional area during fracture demonstrates a $45.12 \%$ decrease from $156 \mathrm{~mm}^{2}$ to $85.61 \mathrm{~mm}^{2}$. Specimen width at fracture was recorded as 20.2 $\mathrm{mm}$, which is $22.21 \%$ less compared to its original width while thickness at fracture equals to $4.2 \mathrm{~mm}-29.45 \%$ less compared to the original thickness.

When reduction of cross sectional area for specimen E3 is considered, values of the maximum stress and stress corresponding to the ultimate tensile strain demonstrated increases of the order of $63.75 \%$ and $24.20 \%$, respectively.

Combining test results obtained for all specimens, it can be observed that there exists a clear trend of increase in stress values with reduction in cross-sectional area. An average of $59.07 \%$ increase is observed in the maximum stress along with a $23.17 \%$ increase in stress value corresponding to the technical ultimate strain (Table 6). If width reduction is the only effect observed, average increase in the maximum stress equals $16.65 \%$. During fracture, specimen cross-sectional areas demonstrated an average reduction of $42.17 \%$ with average reductions of $26.44 \%$ and $21.58 \%$ in thickness and width, respectively. If changes in cross-section areas of the three specimens are 
plotted against applied force (Figure 14), three distinct areas of change can be identified-i.e., the specimens demonstrate a trilinear behavior. The first region corresponds to an almost non-existing change in cross-sectional area prior to yielding; the second region demonstrates minor reduction in cross-sectional area between yielding and realization of the technical ultimate stress; and finally, the third region witnesses significant reduction in crosssectional area starting from the point at which necking occurs.

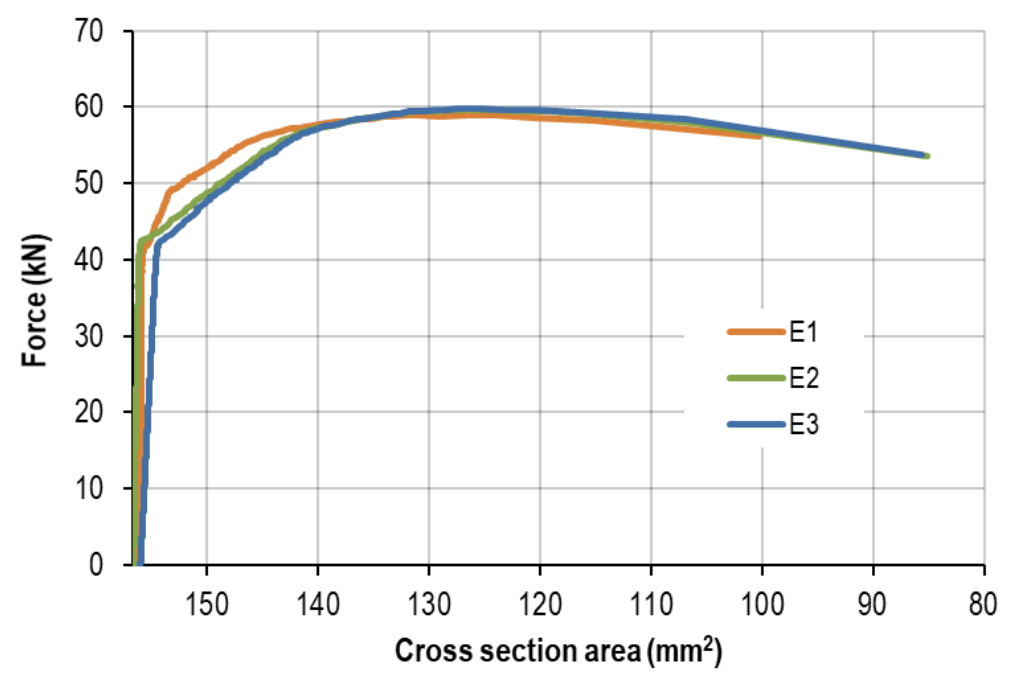

Figure 14 Changes in cross-sectional area with increase in applied force

Identified regions of cross-sectional area reduction clearly indicate that a correlation between true and technical stresses can be deduced based on regions of strain. Up to the value of strain at which yielding occurs and throughout the yielding zone, true stresses could be considered nearly equal to engineering stresses, as described in equation (1).

$$
\sigma_{\text {true }}=\sigma_{\text {eng }}
$$

Up until the point at which necking occurs, a relation suggested by the ANSYS user manual [14] can be considered, as expressed in equation (2).

$$
\sigma_{\text {true }}=\sigma_{\text {eng }} \cdot\left(1+\varepsilon_{\text {eng }}\right)
$$

Equation (2) was validated by comparing stress values corresponding to the technical ultimate tensile stress strain, determined whilst accounting for cross-sectional area reduction (Table 6), against calculated values. For test specimens E1, E2, and E3 true-stress values calculated using equation (2) equaled $460.74 \mathrm{MPa}, 474.03 \mathrm{MPa}$, and $472.06 \mathrm{MPa}$, respectively, while ratios of determined to calculated values were observed to be $0.980,1.012$, and 1.008 (average 1.000), respectively, thereby confirming the validity of equation (2). Although no suggestions are available, at present, to calculate stress values corresponding in the loading region beyond specimen necking, a further linear increase in values of stress is safe to assume based on the trends observed in Figure 15. Therefore, beyond specimen necking, equation (2) could still be applied whilst using the engineering strain at fracture to approximate the true maximum stress. Using strain values determined at fracture, calculated true-stress values were observed to be $524.15 \mathrm{MPa}, 535.73 \mathrm{MPa}$, and $525.20 \mathrm{MPa}$ for specimens $\mathrm{E} 1$, E2, and E3, respectively. Corresponding ratios of determined to calculated stress values at fracture were observed to be 1.069, 1.175, and 1.195, respectively, thereby confirming applicability of the above assumption.

\section{CONCLUSIONS}

This study demonstrates that when performing tensile tests on steel coupons to obtain mechanical properties, obtained results are likely to be influenced by specimen gauge-length choice. In accordance with the EN ISO 68921 [1] standard, different extensometer gauge lengths can be chosen resulting in different strain values being observed at certain applied stresses and vice versa. Cross-sectional area reduction, which occurs with increase in Dokšanović, T, Draganić, H, Radić, I, Damjanović, D 
applied stress, especially during and after specimen necking, is difficult to measure, and is therefore, often neglected. Results obtained corresponding to nominal cross-sectional areas of specimens are generally accepted as valid, although not representative of plasticity. In view of this, use of an optical system for deformation monitoring based on spatial digital-image correlation is proposed in this study to provide insights into above-mentioned influences on test results.

Results of analyses in this study on specimens with six different gauge lengths $-40 \mathrm{~mm}, 50 \mathrm{~mm}, 60 \mathrm{~mm}, 70$ $\mathrm{mm}, 80 \mathrm{~mm}$, and $90 \mathrm{~mm}$-revealed differences between values of important material properties (exceptions being the yield and ultimate stresses). Most significant differences, based on gauge length, were observed in values of the maximum strain (at fracture), which was confirmed by high variability (coefficient of variation values) and an average deviation of $34.75 \%$ between minimum and maximum values. Determined modulus of elasticity values were also observed to be influenced by gauge length, although the values were determined between equal upper and lower stresses. The greatest difference between modulus values corresponding to different gauge lengths used was determined to be a significant $9.64 \%$ - a value close to the determined difference of $8.09 \%$ between strains at yield stress.

As regard true-stress values of specimen steel coupons used in this study, results of analyses performed based on monitoring of specimen cross-sectional area reduction demonstrate existence of significant differences between values of technical and true stresses. At fracture a $42.17 \%$ average reduction in specimen cross-sectional was observed. Correspondingly, the value of maximum stress demonstrated an increase of $59.07 \%$ while the stress value at strain corresponding to the technical ultimate stress was observed to have increased by $23.17 \%$. This implies that reduction in specimen cross-sectional area prior to necking is not negligible. A trilinear functional decrease in cross-sectional area with increase in applied force was determined corresponding to regions bounded by the yield stress, necking, and fracture. Lastly, relations for prediction of true stresses through use of engineering strain have been validated in this study, thereby providing a base for modelling material plasticity without the need to knowing actual stress-strain relationships.

\section{References}

[1] International Organization for Standardization (ISO). 2016: ISO 6892-1, Metallic materials - Tensile testing Part 1: Method of test at room temperature, ISO, Geneva, Switzerland.

[2] Krempl, E. \& Khan, F. 2003: Rate (time)-dependent deformation behavior: an overview of some properties of metals and solid polymers, International Journal of Plasticity, 19 (7), pp. 1069-1095, https://doi.org/10.1016/S0749-6419(03)00002-0

[3] Huang, Y. \& Young, B. 2014: The art of coupon tests, Journal of Constructional Steel Research, 96 (0), pp. 159-175, http://dx.doi.org/10.1016/j.jcsr.2014.01.010

[4] International Organization for Standardization (ISO). 2009: ISO 6892-1, Metallic materials - Tensile testing Part 1: Method of test at room temperature, ISO, Geneva, Switzerland.

[5] Australian Standard (AS). 2007: AS 1391:2007, Metallic materials - Tensile testing at ambient temperature, Standards Australia, Sydney, Australia.

[6] ASTM International. 2013: ASTM E8 / E8M-13a, Standard Test Method for Tension Testing of Metallic Materials, ASTM International, West Conshohocken, Pennsylvania, USA.

[7] Hild, F. \& Roux, S. 2006: Digital Image Correlation: from Displacement Measurement to Identification of Elastic Properties - a Review, Strain, 42 (2), pp. 69-80, https://doi.org/10.1111/j.1475-1305.2006.00258.x

[8] European Committee for Standardization (CEN). 2001: EN 10002-1, Metallic materials - Tensile testing - Part 1: Method of test at ambient temperature, CEN, Brussels, Belgium.

[9] European Committee for Standardization (CEN). 2004: EN 10025-2, Hot rolled products of structural steels Part 2: Technical delivery conditions for non-alloy structural steels, CEN, Brussels, Belgium.

[10] Shimadzu. 2007: Autograph AG-X Series Instruction Manual. Tokyo, Japan: Shimadzu Corporation.

[11] Shimadzu. 2007: Trapezium X Software Reference Manual. Tokyo, Japan: Shimadzu Corporation.

[12] GOMmbH. 2007: ARAMIS User manual - Software, GOM mbH, Braunschweig, Germany.

[13] GOMmbH. 2007: ARAMIS User manual - Hardware, GOM mbH, Braunschweig, Germany.

[14] SAS IP. 2015: ANSYS 17.0. Canonsburg, Pennsylvania, U.S.A.: SAS IP.

Dokšanović, T, Draganić, H, Radić, I, Damjanović, D

https://doi.org/10.13167/2018.16.5 
Please cite this article as:

Dokšanović, T, Draganić, H, Radić, I, Damjanović, D: Stress-strain relationships and influence of testing parameters on coupon test results, Electronic Journal of the Faculty of Civil Engineering Osijek-e-GFOS, 16, pp. 50-63, https://doi.org/10.13167/2018.16.5 